\title{
Somatisms with the Lexemes Láb in Hungarian, Noga in Serbian, and Leg/Foot in English
}

\author{
Sabina HALUPKA-REŠETAR ${ }^{\mathrm{a}}$ \\ Edit ANDRIĆb \\ University of Novi Sad, Faculty of Philosophy (Serbia) \\ ${ }^{a}$ Department of English, ${ }^{b}$ Department of Hungarian \\ halupka.resetar@ff.uns.ac.rs
}

\begin{abstract}
Somatisms are phraseologisms which contain at least one body-part term as a constituent. They make up a considerable part of the phrasemes of any language. In this paper, we focus on the extent to which the equivalent(s) of the term láb occur(s) in Serbian and English somatisms. The research is based on a corpus extracted from both monolingual and bilingual phraseological dictionaries of Hungarian, Serbian, and English. The data are analysed primarily from a cognitive point of view, with the aim of establishing whether the three languages are comparable in terms of the meaning of the idiom as a whole. Degrees of equivalence are established based on whether there is an idiomatic expression in Serbian/English containing the lexeme noga or leg/foot, respectively. Another issue addressed in the paper is the choice of the English term (leg vs foot) in somatisms and the question of whether this choice is arbitrary. Though structure is of secondary importance only, we also take it into account in establishing the degree of equivalence between the items listed in the corpus. Lastly, we stress the similarities and differences noted in the way the body-part terms mentioned are employed in the phraseologisms of the three languages.
\end{abstract}

Keywords: idiom, somatism, body part, Hungarian, Serbian, English

\section{Introduction}

Phraseological units, or set phrases in the broad sense (cf. Burger et al. 1982) have been identified in many languages and in various fields. In spite of this fact, phraseology has only become a discipline in its own right relatively recently. Since it was considered a peripheral issue in linguistics, phraseology was a neglected area of scholarship for a very long time and it is only in the past three decades or so that interest in this subfield of lexicology has considerably grown. The result of this interest is a large number of both theoretical and practical works dealing 
with various aspects of multi-word units and in very different fields ranging from natural language processing to language teaching (Granger and Meunier 2008: xix).

Phraseological units tend to be language specific since they usually express the same abstract semantic concept by different realizations. This suggests that languages may vary substantially with respect to the semantic organization of the lexicon and its interaction with the real world (Colson 2008: 192). It may also serve as a starting point to explore how different languages realize a particular semantic concept, to determine whether similarities or perhaps even universal principles can be established in this respect between genealogically and typologically unrelated languages. It is with this research question that we set out to investigate phraseological units with the term láb 'leg, foot' in Hungarian and its Serbian and English counterparts, noga and leg/foot, respectively. Given that lexemes denoting parts of the body exist in all languages and are thus not part of language-specific vocabulary, the aim of the paper is to explore whether the body parts mentioned are used in phraseologisms with their traditional roles and symbolism (e.g. the head as the generator of ideas) and to what extent we can find correspondence between Hungarian, Serbian, and English in the field of phraseologisms with a particular body part, i.e. whether Serbian and English resort to using the same lexico-semantic field in expressing the same abstract semantic concept.

The paper is structured in the following way: Section 2 identifies the theoretical framework of the study by defining phraseologisms and somatisms. Section 3 gives a brief overview of contrastive research conducted in the area of phraseology and somatisms in particular. Section 4 provides details of the present research, including the corpus, the semantic and structural analyses, and their results. Section 5 sums up the findings of the study and points to future research areas.

\section{Phraseologisms and somatisms}

Being a relatively new field, phraseology often faces terminological challenges. Even the notion phraseology itself has often been defined differently, suggesting that there seems to be no consensus among researchers with respect to the criteria that should be implicated in phraseological research. Cowie (1994: 3168) defines phraseology rather loosely, as "the study of the structure, meaning and use of word combinations". Regarding the criteria, linguists used to distinguish between phraseological and non-phraseological units. Granger and Paquot (2008: 27) point out that the Eastern European tradition has tended to favour fairly fixed combinations like idioms or proverbs but that the more recent corpus-based approaches have adopted a much wider perspective and included many word combinations that would traditionally be considered to fall outside the scope of phraseology. In line with this, Gries (2008: 4) suggests that the nature and number 
of elements involved in a phraseologism should be taken as defining criteria, along with the number of times an expression must be observed before it counts as a phraseologism, the permissible distance between the elements involved, the degree of lexical and syntactic flexibility of the elements involved, as well as the role semantic unity and semantic non-compositionality/non-predictability play in the definition. It is this last criterion that most researchers point out as the most important property of phraseologisms, assuming its elements to function as a single semantic unit, regardless of whether the issue of non-compositionality is part of the definition or not (e.g. Fraser 1976), a necessary condition for a multiword unit to qualify as a phraseologism (Nunberg, Sag, and Wasow 1994). In the present study, a phraseologism will be defined as the co-occurrence of (a form of) a lexical item and one or more additional linguistic elements of various kinds, which functions as one semantic unit in a clause or sentence.

Regarding the question of "semantic unity", phraseologisms can be viewed as being situated along a continuum ranging from most opaque (semantically) and fixed (structurally) to most transparent and variable. For Cowie (1981), pure idioms (e.g. spill the beans) belong to the former end of the continuum and free combinations (e.g. blow a trumpet) to the latter, with figurative idioms (e.g. do a U-turn) and restricted collocations (= collocations, e.g. heavy rain) in between the two ends. As opposed to this top-down approach, Sinclair's (1987) bottom-up corpus-based approach lays much more emphasis on the view of language as being made up of co-selected words that constitute single choices (Granger \& Paquot 2008: 29). The semantic structure of phraseologisms reflects the anthropocentric point of view characteristic of a given nation/ethnic group. The meaning of a large number of phraseologisms is motivated by a body part and they describe various aspects of a human: their age, character, psychological state, behaviour, etc. Phraseologisms which contain at least one body-part constituent are called somatisms (Ziem \& Staffeldt 2011: 196). But while somatisms are expected to be found in all languages, to a higher or lesser degree, and are usually considered to be non-compositional (Kövecses \& Szabó 1996), i.e. their meaning is not the predictable sum of the meanings of their components, in the case of somatisms, it is not arbitrary what the body-part terms denote, and therefore it is well-worth asking to what extent the meaning of a somatism is motivated by the semantic potential of the body-part term it contains. The second important question concerns the reference of the body-part term, which is usually the activity carried out by/with the help of that body part rather than the body part itself (Ziem \& Staffeldt 2011: 196). This, in turn, raises numerous other questions such as whether and to what extent the meaning of phraseologisms is generally grounded in human bodily experience (cf. Gibbs 2006), which cognitive mechanisms systematically motivate the meaning construction, and others, which, for reasons of limited space, we cannot discuss here. 


\section{Previous research}

In this section, we present a brief overview of existing research on phraseology and, more specifically, on somatisms, both in individual languages (especially Hungarian, Serbian, and English) and contrastively.

The phraseological tradition originated in Russia and Germany (Vinogradov 1946, cited in Colson 2008), from where the movement spread to other European countries. A significant portion of research in cross-linguistic phraseology has been conducted by the European Society for Phraseology, focusing on the comparison of German with various European languages (cf. Colson 2008: 192). English soon took over the supremacy, and in the past three decades or so there has been a growing interest in comparing the phraseologisms of English with those of other languages, both European and non-European (for a lengthy list of references, see Colson 2008). There have also been larger projects, comparing the different types of cultural phenomena underlying conventional figurative units in eleven languages (Dobrovol'skij \& Piirainen 2005). The conclusions based on all these studies seem to be the following: the existence of phraseologisms is a universal feature of languages, but differences are observed with respect to the preferred categories of set phrases. Similarly, metaphor has been identified as the key element in the phraseology of all languages, but again, in some languages, simple metaphors are preferred over complex set phrases. There is a close link between culture and phraseology, which is best observed in proverbs and fully idiomatic phrases; however, there is also a common idiomatic heritage to all European languages. Finally, maritime vs. continental culture also appears to play a role in the phraseology of a language (Colson 2008: 192).

Regarding the three languages under scrutiny in this paper, there are several contrastive studies on somatisms, including Csábi (2006) on Hungarian and English, Dragić (2015) on Serbian and English, and Andrić (2013, 2014, 2015).

\section{The present research}

Following Gläser's (1998: 126) claim that idioms may be regarded as the prototype of phraseological units as they form the majority of such items, in this paper, we will restrict ourselves to this type of phraseologisms. In line with Ziem and Stafeldt (2011) and with current cognitive-linguistic research in the domain of phraseology, the assumption we rely on in this paper is that the meaning of idioms can only be fully captured if they are considered to be conceptual in nature (Kövecses \& Szabó 1996), with metaphor and metonymy (Lakoff \& Johnson 2003) being the key cognitive mechanisms involved in the process of constructing idiomatic meaning, i.e. in linking domains of knowledge to idiomatic meaning. 
In what follows, we give a thorough analysis of somatisms with the lexeme láb in Hungarian, noga in Serbian, and leg/foot in English, paying special attention to the way in which the conventional meaning of these body parts motivates the meaning of the idiom. We use Hungarian idioms as the starting point and look for corresponding idioms in Serbian and English to establish whether the idiom is rendered as a somatism involving noga or leg/foot, respectively, and thereby to arrive one step closer to discovering the theoretical principles underlying phraseology as well as its contextual use.

Sinclair's (1987) revolutionary bottom-up approach to phraseologisms, briefly described in the previous section, is corpus-driven. However, since there is still no electronic corpus of Serbian that could be used in the present study, we restricted our attention to several printed dictionaries of phraseologisms and idioms, both monolingual and bilingual, such as Bárdosi (2012), Forgács (2003), Litovkina (2010), and O. Nagy (1966) for Hungarian; Otašević (2012) for Serbian; Seidl and McMordie (1988), Siefring (2004), and Sinclair (1995) for English; bilingual dictionaries like Nagy (2007), Országh (1991), and Varga and Lázár (2000) for Hungarian and English, and Vilijams-Milosavljević and Milosavljević (2001) and Kovačević (2010) for Serbian and English. The only available contemporary Hungarian-Serbian dictionary was Hadrovics and Nyomárkay (2004), which is a rather small-scale dictionary, so we had to rely on our bilingual competence in providing the Serbian equivalents for Hungarian phraseologisms. The crucial concept in examining the idioms is correspondence, defined semantically, i.e. the analysis takes into consideration the meaning of the idiom as a whole, but correspondence is established with regard to the noun láb (i.e. based on whether there is an idiomatic expression in Serbian/English containing this body part).

\subsection{Semantic analysis}

Let us start the analysis by pointing out that both the Hungarian lexeme láb and its Serbian equivalent, noga, have a very rich semantic structure, with senses based on both metaphoric and metonymic extensions of the basic sense, which is "one of the limbs of humans (vertebrates) used for standing on and walking”. In English, however, two lexemes are used: leg (the long, lower limb) and foot (the part of the body used to stand/walk on). It is only logical to expect then that some of the Hungarian (and Serbian) somatisms which do have a somatic equivalent in English will include leg and others will only allow foot. We will try to establish whether a pattern can be observed in this respect.

Regarding the semantics of somatisms containing the lexeme láb (of which we have found nearly 90), a large number of the Hungarian idioms containing this lexeme express movement, with the body part as its object or instrument. In most of these cases, the phraseologism is motivated by the conventional meaning of the 
body-part term, and it describes movement or lack of movement. The movement may be voluntary (húzza a lábát ('drag one’s foot') or medial (e.g. lába kel vminek 'get feet' or lekopik a lába 'walk off one's legs'), as in the following examples:

- a lába elé néz ('look in front of one's foot; gledati pred noge 'look in front of one's feet'; look where one treads); ${ }^{1}$

- fut/menekül ahogy a lába bírja ('run/flee as fast as one's legs can run'; bežati koliko ga noge nose 'run as fast as one's legs will carry one'; run as fast as one's legs can/will carry one);

- szedi/kapkodja a lábát ('collect/rush one’s legs'; pleplitati nogama 'keep crossing one's legs'; skitter, hightail);

- a nyaka köré szedi a lábát ('put one's feet around one's neck'; uzeti put pod noge 'take the road under one's feet'; hit the road, take a hike);

- beteszi a lábát valahova ('put one's foot somewhere'; stupiti gde nogom 'put one's foot somewhere'; tread somewhere);

- húzza a lábát ('drag one's foot'; vući nogu, 'drag one’s foot', trail/drag one’s leg/foot);

- lába kel vminek ('smtg gets legs'; dobiti noge, 'get legs'; take wings, melt into thin air);

- lejárja a lábát ('walk off one's feet'; padati s nogu, 'fall off one’s feet', izgubiti noge 'lose one's feet'; be run off one's legs);

- majd lekopik a lába valami után ('almost wear off one's legs for something'; polomiti noge za čim 'break one’s legs for something', to go out of one’s way for something);

- csak a lábát lógatja ('only dangle one’s feet'; dići sve četiri uvis 'lift all four (= legs) in the air'; rest on one's oars, fold one's hands); ${ }^{2}$

- kézzel-lábbal tiltakozik ('protest/resist with one's arms and legs'; braniti se rukama i nogama 'resist with one's arms and legs'; fight foot and claw/nail).

Several Hungarian idioms with the lexeme láb express the actor's inability to stand, i.e. his physical condition, which may be the result of tiredness, drunkenness, illness, or old age. The body part, thus, expresses a locational relation, e.g.:

- alig áll a lábán ('one barely stands on one’s legs'; jedva se držati na nogama 'barely stand on one's legs'; be dead on one's feet, be ready/fit to drop);

- levesz a lábáról ('take one off one’s feet'; oboriti s nogu 'knock one off one's feet'; knock/sweep one off one's feet, carry one off one's feet);

1 Following each Hungarian example, we provide its literal translation into English, the Serbian idiomatic equivalent, if available, also followed by its literal translation into English, and the corresponding English idiom. All idiomatic expressions are given in italics, non-idiomatic expressions are printed in normal.

2 Interesting to note is the morphological process which turns an intransitive verb into a transitive or causative verb: jár ‘walk’ vs. lejáratja a lábát ‘walk off one’s legs'; lóg 'hang' vs. lógatja a lábát 'dangle one's feet. 
- a lábába száll az ital ('drinks fly (get) into one’s legs'; piće udari kome u glavu 'drinks hit one in the head'; get tipsy/drunk);

- fél lábbal már a koporsóban/sírban van ('with one foot already in the coffin/ grave'; biti/stajati jednom nogom u grobu 'be/stand with one foot in the grave'; have one foot in the grave).

In a similar vein, there are also idioms which describe a psychological state, such as astonishment, excitement, insecurity or security, etc.:

- áll, mint akinek gyökeret vert volna a lába ('stand as if one's legs were rooted in'; stajati kao ukopan 'stand as if entrenched'; stand rooted to the spot, with one's knees/legs turned to jelly);

- gagyibugyi/gyenge lábon áll ('stand on insecure/weak feet'; stajati/biti na klimavim nogama 'stand/be on shaky legs'; (of one's knowledge) rest on weak foundation);

- inog/kicsúszik a lába alatt a talaj ('the ground is shaky/slips under one's feet'; ljulja se kome tlo pod nogama 'the ground sways under one's feet'; have the ground cut from one's feet, be left no leg to stand on);

- szilárdan áll a lábán ('stand firmly on one's feet'; imati čvrsto tlo pod nogama 'have solid ground under one's feet'; have/keep one's feet (set) on the ground, have both feet on the ground);

- bal lábbal kel fel ('get up with one's left foot'; ustati na levu nogu 'get up on one's left foot'; get out of bed on the wrong side).

The function of this body part, i.e. standing, may (metaphorically) represent being independent, conceptualized as being capable of standing on one's own, without support:

- (saját) lábra áll ('stand on one's (own) feet'; stati na svoje noge 'stand on one's own feet'; stand on one's (own) two feet, find one's feet).

A further group of idioms with the lexeme láb relates to social relations and often carries a positive or negative value judgement, as the following examples illustrate:

- a lába kapcája (sem lehet) ('(not fit to be) one's toe rag'; ne biti kome ni do kolena 'not be up to one's knee'; not fit to hold the candle for, cannot be compared with);

- a lába nyomát is megcsókolja ('kiss even one’s footsteps'; ljubiti kome stope 'kiss one's feet'; revere);

- valakinek a lába elé borul ('fall down in front of one's feet'; pasti kome pred noge 'fall down in front of one's feet'; fall at somebody's feet, throw oneself at the feet of somebody);

- lábat vet valakinek ('put out a leg for someone'; podmetnuti kome nogu 'plant a leg for someone'; put a spoke in one's wheels, queer somebody's pitch);

- jó lábon áll valakivel ('stand on good legs with someone'; stajati s kim na dobru nogu 'stand on a good foot with someone'; be on good terms, get on with someone); 
- hadilábon áll valakivel ('stand on war(legs) with'; biti na ratnoj nozi 'be on the war leg'; be at daggers drawn).

Having accounted for the semantics of idioms with the lexeme láb, we next turn to the question of equivalence.

\subsection{Equivalence}

Given that our analysis uses Hungarian as its starting point and examines whether the idioms with the lexeme láb can be rendered by a somatism in Serbian and English and, if so, whether the body part employed corresponds to láb, we can establish three degrees of equivalence:

(1) total equivalence if the semantic content of the Hungarian idiom is conveyed in Serbian/English employing the relevant body part, i.e. noga and leg, respectively;

(2) partial equivalence if the semantic content of the Hungarian idiom is conveyed in Serbian/English employing a different body part. Here, we distinguish between two further degrees depending on whether (a) the body part stands in a meronymic relationship with the Hungarian láb or (b) it is an altogether different part of the body; (3) no equivalence, in the sense that (a) there is an idiom in Serbian/English, but it does not involve any body parts (it rests on a different conceptualization altogether) or (b) for the meaning conveyed by the Hungarian idiom, the dictionaries consulted list no idiomatic expressions in Serbian/English.

The overwhelming majority of the Hungarian idioms listed in Section 4.1 above do have a somatic counterpart in either Serbian or English (the body-part terms printed in bold face). In Table 1, we single out several cases in which we see total equivalence holding between the idiom in Hungarian and that in Serbian and/or English:

Table 1. Illustrations of total equivalence

\begin{tabular}{lll}
\hline \multicolumn{1}{c}{ Hungarian } & \multicolumn{1}{c}{ Serbian } & \multicolumn{1}{c}{ English } \\
\hline $\begin{array}{l}\text { fut/menekül ahogy a lába bírja } \\
\text { 'run/flee as fast as one’s legs } \\
\text { can run' }\end{array}$ & $\begin{array}{l}\text { bežati koliko ga noge nose } \\
\text { run as fast as one's legs will } \\
\text { carry one' }\end{array}$ & $\begin{array}{l}\text { run as fast as one's legs } \\
\text { can/will carry one }\end{array}$ \\
\hline húzza a lábát 'drag one's foot' & vući nogu 'drag one's foot' & trail/drag one's leg/foot \\
\hline $\begin{array}{l}\text { bal lábbal kel fel 'get up with } \\
\text { one’s left foot }\end{array}$ & $\begin{array}{l}\text { ustati na levu nogu 'get up } \\
\text { on one's left foot' }\end{array}$ & - $^{3}$ \\
\hline $\begin{array}{l}\text { lába kel vminek 'smtg gets } \\
\text { legs' }\end{array}$ & dobiti noge 'get legs' & - \\
\hline
\end{tabular}

3 The dash in the table is not to be taken as implying that the idiom has no equivalent in English (or Serbian; cf. tables 2 and 3) but rather that it has no equivalent of the relevant type (illustrated in the table). 
As evidenced by the examples above, even the syntactic structures of the total equivalents are very similar, except in the third case, where the noun láb is instrumental-case marked in Hungarian, whereas in Serbian the corresponding noun occurs in the accusative.

Regarding partial equivalence, we have pointed out that sometimes the idiomatic counterpart reflects a different conceptualization than the Hungarian one, either in terms of (2a) employing a meronym of láb or (2b) other body parts. Table 2 lists several idioms which are in the relationship of partial equivalence with their Serbian and/or English counterparts:

Table 2. Illustrations of partial equivalence

\begin{tabular}{|c|c|c|c|}
\hline & Hungarian & Serbian & English \\
\hline \multirow{3}{*}{ 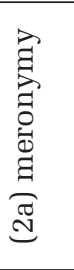 } & $\begin{array}{l}\text { (saját) lábra áll 'stand on } \\
\text { one's (own) feet' }\end{array}$ & - & $\begin{array}{l}\text { stand on one's (own) } \\
\text { two feet, find one's } \\
\text { feet) }\end{array}$ \\
\hline & $\begin{array}{l}\text { a lába nyomát is megcsókolja } \\
\text { 'kiss even one's footsteps' }\end{array}$ & $\begin{array}{l}\text { ljubiti kome stope 'kiss } \\
\text { one's feet' }\end{array}$ & - \\
\hline & $\begin{array}{l}\text { a lába kapcája (sem lehet) } \\
\text { '(not fit to be) one’s toe rag' }\end{array}$ & $\begin{array}{l}\text { ne biti kome ni do kolena } \\
\text { 'not be up to one's knee' }\end{array}$ & - \\
\hline \multirow{4}{*}{ 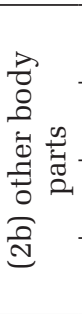 } & $\begin{array}{l}\text { lába kel vminek ‘smtg gets } \\
\text { legs' }\end{array}$ & - & take wings \\
\hline & $\begin{array}{l}\text { a lábába száll az ital 'drinks } \\
\text { fly (get) into one's legs' }\end{array}$ & $\begin{array}{l}\text { piće udari kome u glavu } \\
\text { "drinks hit one in the head' }\end{array}$ & \\
\hline & $\begin{array}{l}\text { csak a lábát lógatja 'only } \\
\text { dangle one’s feet' }\end{array}$ & - & fold one's hands \\
\hline & $\begin{array}{l}\text { megfogja az Isten lábát 'grab } \\
\text { God by the leg'4 }\end{array}$ & $\begin{array}{l}\text { uhvatiti Boga za bradu, } \\
\text { 'grab God by the beard' }\end{array}$ & - \\
\hline
\end{tabular}

It is very interesting to point out that in English the lexeme foot/feet motivates much more idioms than the lexeme leg. In fact, most somatic counterparts of the relevant Hungarian idioms include foot/feet rather than leg. Note, however, the idioms trail/drag one's leg/foot, where the two lexemes under discussion appear to be in free variation, and have the ground cut from one's feet, be left no leg to stand on, two idioms with the same meaning but employing different body parts. Other meronyms of leg also occur occasionally, sometimes even as an alternative to it, as in with one's knees/legs turned to jelly, though other body parts have also been found in English counterparts of Hungarian idioms with the lexeme láb, e.g. fold one's hands or fight foot and claw/nail.

Also worth stressing is that sometimes the body part is 'built into' the idiom in Serbian or English, e.g. stajati kao ukopan 'stand as if entrenched' or look where one treads, both involving the action performed by the relevant body part.

4 The idiom means 'to be very fortunate'. 
The third degree of equivalence proposed above, which is best described as lack of equivalence, encompasses cases in which (3a) the meaning carried by the somatism with the lexeme láb in Hungarian is not expressed by a somatism in Serbian/English, as well as those in which (3b) the relevant Hungarian idiom has no idiomatic counterpart in Serbian/English (in the dictionaries consulted). Table 3 below provides several illustrations for these two cases:

Table 3. Illustrations of no equivalence

\begin{tabular}{|c|c|c|c|}
\hline & Hungarian & Serbian & English \\
\hline \multirow{3}{*}{ 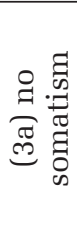 } & $\begin{array}{l}\text { gagyibugyi/gyenge lábon áll } \\
\text { 'stand on insecure/ weak feet' }\end{array}$ & - & rest on weak foundation \\
\hline & $\begin{array}{l}\text { hadilábon áll valakivel 'stand } \\
\text { on war (legs) with' }\end{array}$ & - & be at daggers drawn \\
\hline & $\begin{array}{l}\text { lába kel vminek ‘smtg gets } \\
\text { legs' }\end{array}$ & - & melt into thin air \\
\hline \multirow{4}{*}{ 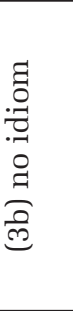 } & $\begin{array}{l}\text { a lábába száll az ital 'drinks } \\
\text { fly (get) into one's legs' }\end{array}$ & 5 & get tipsy/drunk \\
\hline & $\begin{array}{l}\text { szedi/kapkodja a lábát } \\
\text { 'collect/rush one’s legs' }\end{array}$ & & skitter, hightail \\
\hline & $\begin{array}{l}\text { beteszi a lábát valahova 'put } \\
\text { one's foot somewhere' }\end{array}$ & - & tread somewhere \\
\hline & $\begin{array}{l}\text { lábbal tapos/tipor 'tread/ } \\
\text { trample on with one's foot' }\end{array}$ & $\begin{array}{l}\text { grubo pogaziti 'tread } \\
\text { upon violently' }\end{array}$ & $\begin{array}{l}\text { tread/trample } \\
\text { something underfoot }\end{array}$ \\
\hline
\end{tabular}

Very interesting to note is the fact that there seem to be no Hungarian idioms with the lexeme láb which do have a (total or partial) equivalent in English but no equivalent in Serbian. A tentative explanation of this fact is that the over a millennium-long geographic closeness and linguistic contact of Serbian and Hungarian has resulted in the two languages and cultures having very similar conceptualizations. This also suggests that genealogical and typological relatedness might be a less important factor than geographical closeness (as evidenced by the differences between Serbian and English).

The results of the analysis also point to the existence of numerous languagespecific somatisms with the relevant lexemes, e.g. the Hungarian idioms a lába szárába száll az esze ('someone's mind flies into their lower leg', i.e. deteriorates mentally due to old age), három lábon jár ('walk on three legs', i.e. with a walking stick), the Serbian kriti kao guja noge ('hide something like the snake hides its legs'), potući do nogu ('defeat to the feet', i.e. put to the rout) or the English on one's hind legs (standing up to make a speech). However, this comes as no surprise since in the cognitive linguistic tradition idioms are claimed to have conceptual motivation (cf. Lakoff 1987), which means that the meaning of

5 There are, of course, non-idiomatic Serbian equivalents of the relevant idioms, but these are of no interest to us here. 
many idioms seems natural and transparent to us exactly because conceptual metaphor and metonymy and/or conventional knowledge link the non-idiomatic meaning of the constituent words to the idiomatic meaning of the idiom. On the other hand, variation and alternative conceptualizations are also expected to occur as the result of the specific cultural context (governing principles and key concepts in different cultures), social concerns (different frequency of somatisms and of particular body parts used in them), cognitive preferences (differences in the experiential focus and metaphor and metonymy preference), styles, and coherence (cf. Kövecses 2005). Thus, culture-specific actions can be referred to in some cases as a result of which culture-specific content is provided for the similar generic structure (Csábi 2006).

\section{Concluding remarks}

Comparing idioms, the "central and most important class of phrasemes" (Dobrovol'skij and Piirainen 2005: 39), is particularly useful in several languages for analysing cultural phenomena. In this paper, we took as the starting point Hungarian idioms with the body part term láb and explored the extent to which the meaning of the idioms this lexeme motivates in Hungarian are realized as somatisms with the corresponding terms in Serbian and English. The results of the analysis show that although the universal bodily basis can, it does not have to be utilized in the same way in different languages (cf. Csábi 2006). This is most evident in the fact that a large number of English somatic equivalents of the Hungarian idioms employ the lexeme foot rather than leg. Differences can also be the result of experiential focus, as different people (and different cultures) may highlight different aspects of their bodily functioning.

Any comparison between figurative units in several languages undoubtedly unveils a number of interesting cognitive and semantic principles. At the same time, the image component is influenced by the culture of a specific language, and can therefore yield a lot of information about differences in culture (Colson 2008: 196). This small-scale research suggests that geographic closeness and linguistic contact may result in very similar conceptualizations as a large number of Hungarian somatisms with the lexeme láb have been found to have total or partial equivalents in Serbian (but much less so in English). Further research should therefore focus on those phraseologisms involving the lexemes noga in Serbian and leg/foot in English the Hungarian equivalents of which do not contain the lexeme láb. Furthermore, the validity of the above hypothesis should be checked by exploring the extent to which equivalents of various types of phraseologisms can be found in genetically and/or typologically unrelated languages which are geographically close. 


\section{Acknowledgements}

The authors acknowledge funding from Project No. 178002 of the Ministry of Education, Science and Technology of the Republic of Serbia, entitled Languages and Cultures in Time and Space.

\section{References}

Andrić, Edita. 2013. Kontrastivna semantička analiza reči fej u mađarskom i glava u srpskom jeziku [A contrastive semantic analysis of the word fej in Hungarian and the word glava in Serbian]. Zbornik matice srpske za filologiju i lingvistiku LVI/2: 131-153.

Andrić, Edit. 2014. A fej vezérszavú frazeológiai egységek a magyarban és szerb ekvivalenseik [Hungarian phraseological units with the head word fej and their Serbian equivalents]. Sedmi međunarodni interdisciplinarni simpozijum Susret kultura, Zbornik radova, 19-29. Novi Sad: Filozofski fakultet.

Andrić, Edita. 2015. Oko za oko. Kontrastivna frazeološka analiza sa odrednicom szem/oko u mađarskom i srpskom jeziku. Peti međunarodni kongres „Primenjena lingvistika danas”. Nove tendencije u teoriji i praksi [An eye for an eye: contrastive phraseological analysis of the head words szem in Hungarian and oko in Serbian]. 27-29 November 2015. Filozofski fakultet, Novi Sad.

Bárdosi, Vilmos. 2012. A magyar szólások, közmondások értelmezó szótára fogalomköri szómutatóval [Dictionary of Hungarian idioms and proverbs]. Budapest: Tinta Könyvkiadó.

2013. Lassan a testtel! Emberi testrészek a magyar szólásokban, közmondásokban [Body-part terms in Hungarian idioms and proverbs]. Budapest: Tinta Kiadó.

Burger, Harald-Buhofer, Annelies-Sialm, Ambros-Brigit Erikson (eds). 1982. Handbuch der Phraseologie. Berlin: de Gruyter.

Colson, Jean-Pierre. 2008. Cross-linguistic phraseological studies. In: Granger, Sylviane, Meunier, Fanny (eds), Phraseology. An interdisciplinary perspective, 191-206. Amsterdam/Philadelphia: John Benjamins Publishing Company.

Cowie, Anthony Paul. 1981. The treatment of collocations and idioms in learners' dictionaries. Applied Linguistics 2(3): 223-235.

Cowie, Anthony Paul. 1994. Phraseology. In: Asher, R. E. (ed.), The encyclopedia of language and linguistics, 3168-3171. Oxford: Oxford University Press.

Csábi, Szilvia. 2006. The comparison of the motivation of English idioms and their Hungarian equivalents. In: Corino, E., Marello, C., C. Onesti (eds), Proceedings of the $12^{\text {th }}$ EURALEX International Congress, 951-957. Edizioni dell' Orso.

Dobrovol'skij, Dmitrii-Elisabeth Piirainen. 2005. Figurative language. Crosscultural and cross-linguistic perspectives. Amsterdam: Elsevier. 
Dragić, Mila. 2015. Frazeologizmi sa leksemom jezik i ciljnim domenom jezičke radnje u srpskom i engleskom jeziku [Phraseologisms with the lexeme jezik 'tongue' and target domain of verbal action in Serbian and English]. Zbornik za jezike i književnosti Filozofskog fakulteta u Novom Sadu 5: 9-20.

Forgács, Tamás. 2003. Magyar szólások és közmondások szótára [Dictionary of Hungarian idioms and proverbs]. Budapest: Tinta Könyvkiadó.

Fraser, Bruce. 1976. The Verb-particle combination in English. New York, NY: Academic Press.

Gibbs, Raymond W. Jr. 2006. Embodiment and cognitive science. Cambridge, MA: Cambridge University Press.

Gläser, Rosemarie. 1998. The stylistic potential of phraseological units in the light of genre analysis. In: Cowie, A. P. (ed.), Phraseology. Theory, analysis, and applications, 125-143. Oxford: Oxford University Press.

Granger, Sylviane-Magali, Paquot. 2008. Disentangling the phraseological web. In: Granger, Sylviane, Meunier, Fanny (eds), Phraseology. An interdisciplinary perspective, 27-49. Amsterdam/Philadelphia: John Benjamins Publishing Company.

Hadrovics, László-Nyomárkay, István. 2004. Magyar-szerb kisszótár [HungarianSerbian small dictionary]. Budapest: Akadémiai Kiadó.

Kovačević, Živorad. 2010. Frazeološki rečnik srpsko engleski [Serbian-English dictionary of phraseologisms]. Beograd: Građevinska knjiga.

Kövecses, Zoltán-Szabó, Péter. 1996. Idioms: a view from cognitive semantics. Applied Linguistics 17 (3): 326-355.

Lakoff, George-Johnson, Mark. 2003. Metaphors we live by. $2^{\text {nd }}$ ed. Chicago: The University of Chicago Press.

Litovkina, Anna T. 2010. Magyar közmondások nagyszótára [Comprehensive dictionary of Hungarian proverbs]. Budapest: Tinta Könyvkiadó.

Matešić, Josip. 1982. Frazeološki rječnik hrvatskoga ili srpskoga jezika [Dictionary of Croatian or Serbian phraseologisms]. Zagreb: Školska knjiga.

Nagy, György. 2007. Magyar-angol idiómaszótár [English-Hungarian dictionary of idioms]. Budapest: Akadémiai Kiadó.

Nikolić, Miroslav (ed.). 2007. Rečnik srpskoga jezika [A dictionary of the Serbian language]. Novi Sad: Matica srpska.

Nunberg, Geoffrey-Sag, Ivan Andrew-Wasow, Tom. 1994. Idioms. Language 70(3): 491-538.

O. Nagy, Gábor. 1966. Magyar szólások és közmondások [Hungarian idioms and proverbs]. Budapest: Gondolat.

Országh, László. 1991. Magyar-angol nagyszótár [Hungarian-English Dictionary]. $9^{\text {th }}$ ed. Budapest: Akadémiai Kiadó.

Otašević, Đorđe. 2012. Frazeološki rečnik srpskoga jezika [Phraseological dictionary of Serbian]. Novi Sad: Prometej. 
Puszta, Ferenc (ed.). 2003. Magyar értelmezó kéziszótár [The concise dictionary of the Hungarian language]. $2^{\text {nd }}$ ed. Budapest: Akadémiai Kiadó.

Seidl, Jennifer-McMordie, William. 1988. English idioms. $5^{\text {th }}$ ed. Oxford: Oxford University Press.

Siefring, Judith (ed.). 2004. The Oxford dictionary of idioms. $2^{\text {nd }}$ ed. Oxford: Oxford University Press.

Sinclair, John (ed.). 1987. Looking up. An account of the COBUILD project in lexical computing. London: Collins Cobuild.

1995. Collins COBUILD dictionary of idioms. London: Harper Collins Publishers Ltd.

Varga, György-Lázár, Péter. 2000. Magyar-angol kéziszótár [Hungarian-English concise dictionary]. $5^{\text {th }}$ ed. Budapest: Aquila Kiadó.

Vilijams-Milosavljević, Margot-Milosavljević, Boško. 2001. Englesko-srpski frazeološki rečnik [English-Serbian phraseological dictionary]. Beograd: Istočnik.

Ziem, Alexander-Staffeldt, Sven. 2011. Compositional and embodied meanings of somatisms. In: Schönefeld, Doris (ed.), Converging evidence: methodological and theoretical issues for linguistic research, 195-219. Amsterdam/ Philadelphia: John Benjamins Publishing Company. 